\title{
Current Progress in Nitrogen Fixing Plants and Microbiome Research
}

\author{
Kishan Mahmud ${ }^{1}$, Shiva Makaju ${ }^{2}{ }^{(1)}$, Razi Ibrahim ${ }^{3}$ and Ali Missaoui 1,2,3,* \\ 1 Center for Applied Genetic Technologies, University of Georgia, Athens, GA 30602, USA; \\ Kishan.mahmud25@uga.edu \\ 2 Department of Crop and Soil Sciences, University of Georgia, Athens, GA 30602, USA; shmakaju@uga.edu \\ 3 Institute of Plant Breeding, Genetics and Genomics, University of Georgia, Athens, GA 30602, USA; \\ Razi.Ibrahim@uga.edu \\ * Correspondence: cssamm@uga.edu; Tel.: +1-706-542-8847
}

Received: 16 December 2019; Accepted: 8 January 2020; Published: 13 January 2020

\begin{abstract}
In agroecosystems, nitrogen is one of the major nutrients limiting plant growth. To meet the increased nitrogen demand in agriculture, synthetic fertilizers have been used extensively in the latter part of the twentieth century, which have led to environmental challenges such as nitrate pollution. Biological nitrogen fixation (BNF) in plants is an essential mechanism for sustainable agricultural production and healthy ecosystem functioning. BNF by legumes and associative, endosymbiotic, and endophytic nitrogen fixation in non-legumes play major roles in reducing the use of synthetic nitrogen fertilizer in agriculture, increased plant nutrient content, and soil health reclamation. This review discusses the process of nitrogen-fixation in plants, nodule formation, the genes involved in plant-rhizobia interaction, and nitrogen-fixing legume and non-legume plants. This review also elaborates on current research efforts involved in transferring nitrogen-fixing mechanisms from legumes to non-legumes, especially to economically important crops such as rice, maize, and wheat at the molecular level and relevant other techniques involving the manipulation of soil microbiome for plant benefits in the non-legume root environment.
\end{abstract}

Keywords: biological nitrogen fixation; nitrogenase; nif genes; legumes and nodules; associative nitrogen fixation; soil microbiome; rhizosphere

\section{Introduction}

A healthy, functioning soil ensures nutrient cycling for optimum plant growth for agricultural production [1]. However, agricultural productivity is often limited by available soil nutrients, especially nitrogen [2]. Nitrogen is not present in soil parent material despite the fact that nitrogen content in the atmosphere is highest among all the atmospheric gases [3]. Hence, soil nitrogen input for plant nutrition and crop productivity largely depends on organic matter degradation, synthetic fertilizer applications, and biological nitrogen fixation (BNF) via nitrogenase enzyme activity [4,5]. This limited bio-availability of $\mathrm{N}$ and the escalating reliance of crop growth on $\mathrm{N}$ have created a colossal $\mathrm{N}$-based fertilizer industry worldwide [6,7]. Nitrogenous fertilizer production currently represents a significant expense for the efficient growth of various crops in the developed world. Synthetic $\mathrm{N}$ fertilizers are currently used in grain, grass, and fruit productions (about $60 \%$ for cereals and 10\% with irrigated rice production) [8]. More than $50 \%$ of the applied N-based fertilizer is used by the plants and the remaining can be subjected to losses like surface runoff and leaching leading to nitrate contamination of soils and groundwater. In terms of energy efficiency, moreover, manufacturing nitrogen-based fertilizers requires six times more energy than that needed to produce either phosphorous or potassium based fertilizers [9]. Therefore, reducing dependence on nitrogenous fertilizers in agriculture in the developed world 
and developing countries may lead to potential gains in an agricultural setting. Biological nitrogen fixation (BNF) in economically important food and forage crops [10] has drawn attention to achieve sustainable agricultural goals in both both hemisphere of the world [11]. In livestock production systems in southeastern USA, strategically planting nitrogen-fixing legumes in cattle pastures has shown to increase the available soil nitrogen [12], thereby reducing the need to apply synthetic nitrogen sources. The diazotrophic microorganisms from bacteria or archaea domains are responsible for BNF and only some prokaryotes are able to use atmospheric nitrogen through BNF by encoding nitrogenase, an enzyme that catalyzes the conversion of $\mathrm{N}_{2}$ gas to ammonia $\left(\mathrm{NH}_{3}\right)[8,13,14]$. Despite the phylogenic and ecological diversity among diazotrophic bacteria and their hosts, a synchronized interaction is always a prerequisite between the microbial entities and the host plant to achieve a successful nitrogen fixation system. The importance of this process is enormous as it reduces the dependence on nitrogen fertilizers for plants and thus, for agriculture overall. It has been estimated that worldwide, biological nitrogen fixation produces roughly 200 million tons of nitrogen annually [15,16]. In fact, nearly 50\% of the total nitrogen in crop fields is the contribution of BNF by diazotrophic bacteria of the total biosphere nitrogen [17]. Moreover, fixed nitrogen can also be transferred to intercropped non-legumes in the case of mixed cropping systems, such as the soybean-wheat system, or the next season crops in crop rotation [18]. In this review article, we explore current developments concerning the limitations and potential promises of nitrogen fixation in legumes and non-legumes.

\section{Biological Nitrogen Fixation (BNF)}

Nitrogen fixation is a dynamic and high energy demanding process [19]. The pathway for the biological reduction of inert $\mathrm{N}_{2}$ into the reactive compound $\mathrm{NH}_{3}$ (ammonia) under micro-aerobic conditions is as follows:

$$
\mathrm{N}_{2}+8 \mathrm{H}^{+}+8 \mathrm{e}^{-}+16 \mathrm{Mg}-\mathrm{ATP} \rightarrow 2 \mathrm{NH}_{3}+\mathrm{H}_{2}+16 \mathrm{Mg}-\mathrm{ADP}+16 \mathrm{P}
$$

Free-living diazotrophs correspond to a small fraction of the plant rhizospheres ecosystem, and they belong to alphaproteobacteria (Rhizobia, Bradyrhizobia, Rhodobacteria), betaproteobacteria (Burkholderia, Nitrosospira), gammaproteobacteria (Pseudomonas, Xanthomonus), firmicutes, and cyanobacteria [20]. However, their presence, function, and importance can be explained by the "black queen" hypothesis which predicts that in free-living microbial communities, only a few "helpers" that carry the heaviest weight in terms of functions, such as high energy-requiring nitrogen fixation, support the rest of the flora and fauna population or the "beneficiaries" that rely on the "helpers" or the "beneficials" for nitrogen needs [21].

The symbiotic relationship between soil bacteria, collectively known as rhizobia (which includes the genera Rhizobium, Bradyrhizobium, Mesorhizobium, and Sinorhizobium), and legume roots generates nodules (a new differentiated special organ) that fix atmospheric nitrogen through the action of the nitrogenase enzyme [22]. BNF by plants and its bacterial associations represent an important natural system for capturing atmospheric $\mathrm{N}$ and processing it into a reactive form of nitrogen through enzymatic reduction. BNF is considered an extremely sensitive process influenced by nutrient and environmental conditions and enables a plant to supply all or part of its requirements through interactions with endo-symbiotic, associative, and endophytic symbionts, thus offering a competitive advantage over any non-nitrogen-fixing plants [15,23-26]. The highly conserved nitrogenase complex in free-living and symbiotic diazotrophs enables them to participate in various types of associations/interactions with their host plants. BNF by plant-rhizobia symbiotic systems is mediated by endosymbiotic interaction when plants develop root nodules; in legumes and rhizobia, gram-negative alpha proteobacteria are the most common microbial species that associate (endo-symbiotic interaction) with legumes of the Fabaceae (Papilionaceae) family [27-29]. Actinomycetes such as the Parasponia species (family Cannabaceae) and Frankia sp. that associate with a broad spectrum of actinorhizal plants are well documented in nitrogen fixation as well [8]. Cyanobacteria (mainly Nostoc sp.) have also been found 
to colonize different plant organs, either intracellularly in the family Gunneraceae or extracellularly in Azolla, Cycadaceae, liverworts and hornworts. Associative nitrogen fixation (ANF) and/or endophytic symbioses are often observed among diazotrophs, such as Azospirillum spp., Azoarcus spp. and Herbaspirillum, with a wide variety of plant roots including cereals. The nitrogenase protein, as well as the associated proteins and non-proteins forming nitrogenase enzyme, are sensitive to the presence of oxygen [30]. For this extreme sensitivity to oxygen, obligate anaerobes such as Clostridium pasteurianum are ideal candidates for nitrogen fixation; however, facultative anaerobes such as Klebsiella oxytoca are also capable of fixing nitrogen but only when the oxygen is absent in the system [31]. Obligate aerobes, such as Azotobacter vinelandii can also shield nitrogenase from oxygen and perform nitrogen fixation by consuming oxygen via cytochrome oxidases [31,32].

\subsection{The Nitrogenase Protein and Nodule Formation}

As mentioned earlier, a protein complex called nitrogenase (composed of enzymes with metal co-factors) makes nitrogen fixation possible in plants. The first one is dinitrogenase and the second one is dinitrogenase reductase [33]. According to the active site co-factor binding metal, there exist three types of dinitrogenase in nature. (a) Molybdenum (Mo) nitrogenase; it is most abundant and carries the most significance in the nitrogen-fixing bacterial and archaeal niche and the alternative vanadium (V) and iron-only (Fe) nitrogenases [34]. The molybdenum dependent dinitrogenase is formed by nifD and nifK gene products and dinitrogenase reductase is a homodimer of the nifH gene product $[30,35]$. It is well documented that molybdenum nitrogenase is produced in all diazotrophs in nature, while some produce the vanadium or iron nitrogenase addition to Mo-nitrogenase [36,37]. The rhizobium bacteria residing in nodules fix atmospheric nitrogen gas to $\mathrm{NH}_{3}$, which plants can assimilate via glutamine synthase to form glutamine. In response, the bacteria derive plant carbohydrates, mainly as malate for food and an energy source for nitrogen fixation. Nodules are very complex structures, containing several processes which operate and interact at distinct levels. The process of nodule formation requires a coordinated exchange of signals between the two symbiotic partners [38]. Bacteria had their symbiotic genes first characterized by transposon mutagenesis; this achieved the definition of over 50 nodulation genes (Nod and Nol) in bacteria, and about the same number controlling nitrogen fixation; thus many nod- and fix-bacterial strains exist in many species of rhizobia. Legume-rhizobium symbiosis starts with molecular signaling between the two partners. Early nodulation gene cascades in legumes. Plants release signals such as flavonoids (e.g., the flavone 7,4 dihydroxyflavone and the isoflavone genistein) which are picked up by compatible bacteria in the rhizosphere [39,40] leading to the production of Nod factors (NF) which trigger early events in the nodulation process [41,42]. This triggers the downstream gene cascade including those involved in nucleoporin, cation channels, calcium spiking, early nodule expression, and cytokine signaling leading to cortical and pericyclic cell divisions, and concomitant bacterial infection. Rhizobia are entrapped by root hair curling after the Nod factor has been perceived, which results in initiating the formation of infection thread (a tubular structure). This infection thread facilitates the penetration of root hair cells and adjacent cortical cells [43]. Cell divisions in cortical and pericycle occur simultaneously resulting in the formation of the nodule primordium. Bacterial cell division facilitates the rhizobial traveling through the infection thread and is eventually freed into the induced nodule primordium cells [44,45]. As nodules mature with time, bacteria are enclosed within the symbiosome membrane, resultant from an inverted plasma membrane of plant origin. In this encapsulated chamber, the bacteria experience a micro-aerobic environment (lower oxygen concentration) and differentiate into bacteroids, fixing diffused nitrogen gas using their nitrogenase enzyme complex [46,47]. Depending on whether or not the meristem remains active for the life of the nodule, two main types of nodules are formed on the various legume species, (i) indeterminate or (ii) determinate. In the case of determinate nodules, nodular meristematic activity is terminated early and is usually initiated sub-epidermally in the outer cortex, thus giving rise to spherical nodules [48]. In indeterminate nodules, the inner cortex undergoes cell division 
(anticlinally) followed by periclinal divisions in the pericycle. Here, cylindrical nodules are formed due to more persistent meristems [49,50].

\subsection{Genes Encoding Nitrogenase Enzyme}

The understanding of the genetic basis of this relationship is of paramount importance and essential for the optimization of nitrogen acquisition rates in legumes themselves. Bacterial nif genes are well known to encode the components of the nitrogenase enzyme complex. nifH, nifD, and nifK genes encode the structural subunit of di-nitrogenase reductase and the 2 subunits of di-nitrogenase, respectively. Many rhizobial genes have been fully sequenced, for instance, Mesorhizobium loti, Sinorhizobium meliloti, and Bradyrhizobium japonicum [51-53]. These proteins have similar sequences and common structures and functions in many diazotrophs, for instance, Azotobacter vinelandii, Herbaspirillum seropedicae, Pseudomonas stutzeri, and Bradyrhizobium japonicum [54-57]. Furthermore, genetic and biochemical analyses revealed that many additional nif genes, including nifE, nif $N$, nif $X$, nif $Q$, nif $W$, nif $V$, nifA, nifB, nifZ, and nifS, play roles in the regulation of nif genes and maturation processes of electron transport and FeMo-cofactor biosynthesis and assembly [58,59]. In addition, the fix $A B C X$ genes first identified in Rhizobium meliloti [60,61] and subsequently in other diazotrophs were reported to encode a membrane complex participating in electron transfer to nitrogenase [62]. The degree of specificity between legumes and rhizobia varies. The Nod factors produced by Rhizobium etli and Rhizobium loti produce identical Nod factors; however, they have distinct host ranges (Phaseolus spp. and Lotus spp., respectively) [63]. Moreover, different rhizobia nodulating the same plant may excrete completely different Nod factors. For instance, Rhizobium tropici and R. etli produce different Nod factors (sulfated and acetylfucosylated, respectively), but both are known to nodulate Proteus vulgaris [64]. More examples include Bradyrhizobium elkanii and Bradyrhizobium japonicum, which have a number of mutual hosts, but their Nod factors differ considerably [65].

\subsection{Marker-Assisted Selection of Biological Nitrogen-Fixing Plants}

Several studies have identified QTL associated with traits related to biological $\mathrm{N}$ fixation (Table 1 [66-69]). The QTL markers can be used in marker-assisted selection for breeding plants with better nitrogen fixation attributes. A QTL for the total ureides (acyl derivatives of urea) was identified on chromosome 17 in soybean which explained $13.26 \%$ phenotypic variation [70]. $\mathrm{Li}$ and the team [71] cloned a candidate gene associated with a major QTL in soybean for increasing nodule size and named it INCREASING NODULE SIZE1 (GmINS1). The overexpression of GmINS1 increased the N content and the biomass of the soybean plant due to an increase in number, biomass, the abundance of infection cells, and nitrogenase activity of large nodules [71]. The result was the opposite when GmINS1 was suppressed by RNA interference [71]. 
Table 1. Major genomic loci detected for BNF in different legume species [66-69].

\begin{tabular}{|c|c|c|c|c|}
\hline Species & Chromosome Number & QTL or Marker Interval & Plant Response & QTL-Effect, $\mathbf{R}^{2}(\%)$ \\
\hline Common bean (Phaseolus vulgaris L.) & 7 & $N d f a 7.1^{D B, S A}$ & $\mathrm{~N}$ derived from atmosphere (Ndfa) & 14.9 \\
\hline Soybean [Glycine max (L.) Merr.] & 16 & $q B N F-16$ & Nodule size \& number & $15.9-59$ \\
\hline Soybean [Glycine max (L.) Merr.] & 17 & $q B N F-17$ & Nodule size \& number & $12.6-18.6$ \\
\hline Lotus japonicus & 2 & TM0550-TM0324 & Acetylene reduction activity per plant (ARA/P) & 15.1 \\
\hline Lotus japonicus & 2 & TM0550-TM0002 & ARA per nodule number (ARA/NN) & 11.1 \\
\hline Lotus japonicus & 4 & TM0664 & ARA per nodule weight (ARA/NW) & 10.8 \\
\hline Lotus japonicus & 5 & TM1417-TM0095 & ARA per nodule weight (ARA/NW) & 13 \\
\hline Lotus japonicus & 3 & TM0083 & Nodule number (NN) & 21.6 \\
\hline Lotus japonicus & 1 & TM0113-TM0805 & Stem length (SL) & 13.3 \\
\hline Lotus japonicus & 1 & TM0027-TM0063 & Shoot length without inoculation (SL bac-) & 16.7 \\
\hline Lotus japonicus & 1 & TM0113-TM0805 & Shoot length without inoculation (SL bac-) & 16 \\
\hline Lotus japonicus & 5 & TM0095-TM0909 & Shoot dry weight without inoculation (SW bac-) & 10.7 \\
\hline Cowpea [Vigna unguiculata (L.) Walp.] & 4 (Likage group) & 2_12850/2_54418 & Nodule number & 48.4 \\
\hline Cowpea [Vigna unguiculata (L.) Walp.] & 6 (Likage group) & 2_11936/2_49231 & Nodule fresh weight & 21.4 \\
\hline
\end{tabular}




\section{Host Plant}

Plants are associated with a complex microbiome that contributes to plant nutrient assimilation, growth, and defense. Nitrogen-fixing microbial associations are efficient and well-characterized in legumes but are limited in cereals, including maize. Plants contribute substantially toward the organic carbon pool of soil in the form of lysed cells, mucilage, and root exudates [72]. Root exudates are a complex mixture of simple and complex sugars, amino and organic acids, fatty acids and vitamins [73]. Depending on the plant genotype and growth stage, soil texture, nutrient status of soil, water holding capacity of the soil and, most importantly, the rhizosphere microbial communities, the amount and types of exudates will vary. In turn, root exudate composition in the rhizosphere can influence the soil microbial community and availability of macro and micronutrients, especially nitrogen and phosphorus [74]. The root exudate composition also serves as a recruiting complex of unique prokaryotic and eukaryotic populations [75]. More interestingly, the build of specific microbiota by secreting particular carbon sources is often observed, for instance, dicarboxylates in tomato root exudates favor the growth of pseudomonas biocontrol strains and pea plants excrete homoserine to select Rhizobium leguminosarum [76-80]. Plants can also defend themselves through the secretion of phytochemicals that can inhibit the growth of certain microbial entities [80]. The ability to tolerate these chemicals can play an important role in the ability to colonize the plant. For example, the PGPR Pseudomonas putida is both tolerant of and attracted by the main antimicrobial benzoxazinoid produced by maize (a non-legume plant) [81]. In addition, transgenic plants expressing opine biosynthesis genes shown to redesign current rhizosphere populations to increase the densities of opine-catabolizing bacteria compared to wild-type $[82,83]$.

\subsection{Symbiotic Nitrogen Fixation in Legume Nodules}

In both natural and cultivated ecosystems, legumes supply a significant amount of nitrogen [84-86], and the nitrogen fixed by perennial forage legumes can be as high as the amounts of nitrogen fertilizers used in conventional farming practices $[87,88]$. Moreover, rhizodeposition from legumes is another substantial source of available nitrogen and other essential plant nutrients in rhizosphere [89-91]. In temperate forests, a $28 \%$ increase in nitrogen availability was reported due to the direct effect of BNF and the indirect effect of rhizodeposition [92]. In North America, several leguminous plants such as pea (Pisum sativum L.), faba bean (Vicia faba ssp minor L.), and dry bean (Phaseolus vulgaris L.) are mainly produced for animal and poultry feed [18]. The most common legumes for human consumption are dry bean, chickpea (Cicer arietinum L.) and cowpea (Vigna unguiculata L.), lentil (Lens esculenta L.), pigeon pea (Cajanus cajan L.), and peanut (Arachis hypogea L.). All these legumes are capable of nitrogen-fixation and are often grown in intercropping or for crop rotation. Nitrogen fixed by symbiotic association of soybean root system with soil bacteria (Rhizobia) has a significant contribution to the growth, development, and maturity stages. The increase in nitrogen fixation capacity can be translated to the increase in plant parts including soybean pods. In the field-grown soybean [Glycine $\max ($ L.) Merrill] cv. Chippewa in a Typic Eutrocrepts soil at physiological maturity (R7), the amounts of nitrogen derived from fixation ( $N d f s$ ), nitrogen from soil, and ${ }^{15} \mathrm{~N}$-labelled fertilizer $(\mathrm{Ndff})$ were $47 \%$, $50 \%$, and $3 \%$, respectively [93]. The contribution of nitrogen in soybean pods and seeds was higher from fixed nitrogen (55\%) compared to the nitrogen from soil (43\%) [93]. Muñoz, Qi [70] observed cultivated soybeans were more efficient in BNF compared to the wild soybeans.

Forage legumes are grown under a broad climatic spectrum, and they have the potential to give higher yield and provide essential nitrogen to the soil. The four major forage legumes, alfalfa (Medicago sativa L.), red clover (Trifolium pratense L.), subterranean clover (T. subterraneum L.), and white clover (T. repens L.) together comprise most of the hot and arid regions on earth's grasslands [94]. Alfalfa (Medicago saliva L.) is a cool-season perennial forage legume that obtains nitrogen from the soil and the BNF through symbiotic association of its root nodules with soil bacteria. For its ability to provide fixed nitrogen, alfalfa is increasingly gaining popularity as a companion forage in grass pastures [95]. The fixed nitrogen by alfalfa is not only used by itself but also is transferred to the subsequent crops, 
which is also termed as a "niche complementarity effect" [96]. For example, the transfer of nitrogen fixed by alfalfa to different grass species such as timothy (Phleum pratense L.) and bromegrass (Bromus inermis Leyss) was demonstrated using the ${ }^{15} \mathrm{~N}$ dilution technique [97]. Heichel, Barnes [97] observed the contribution of $\mathrm{N}$ transfer from alfalfa to associated grasses in terms of absolute amounts at 5, 20, and $19 \mathrm{~kg} \mathrm{~N} \mathrm{ha}^{-1}$ for the three test years, respectively. The direct excretion of $\mathrm{N}$ compounds from the root system and the decomposition of root and nodule debris were attributed to this contribution [97].

In addition to economically important crops and forages, considerable attention has been given to several plant species that can produce biofuel while fixing nitrogen. One important example is Pongamia pinnata, which in addition to being a medicinal and green manure plant, can nodulate with several strains of both Bradyrhizobium and Rhizobium; however, best-selected inocula were B. japonicum strains CB1809 and USDA110 [98-100]. Pongamia resembles the general properties seen in annual legumes such as soybean and its nodules actively fix nitrogen where acetylene is reduced by bacterially encoded nitrogenase [101]. However, in addition, many current plant biofuel feedstocks such as oil palm, canola, willow, corn (Zea mays), sugarcane, jatropha, sorghum, and even algae may produce abundant fuels but are not nitrogen-fixing species [38].

\subsection{Nitrogen Fixation in Non-Legumes}

In a non-symbiotic system such as rhizosphere-associative nitrogen fixation, nitrogen-fixing bacteria fix the nitrogen by using carbon and energy sources supplied from the environment, and the bacteria release fixed $\mathrm{N}$ probably after lysis of the bacterial cells [102,103]. Symbiotic bacteria such as rhizobia and Frankia are located in nodules, whereas in rhizosphere-associative systems, the diazotrophic bacteria are essential in the free-living state and fix nitrogen using the supply of carbohydrates from the environment [104,105] in accord with the excretion of carbohydrates from the roots and the degradation of soil organic matter. In contrast to the legume-rhizobia symbiotic system in nodules, the associations of plants and microbes in rhizosphere soils and plant root interiors form adjusted or adapted nitrogen-fixing systems under physiologically nitrogen-deficient but energy-sufficient conditions. Over the last 50 years, nitrogen fixation in no-leguminous crops and bacterial associations have been investigated elaborately for their agronomic significance. For example, associative nitrogen fixation in sugarcane (Saccharum spp.), sweet potato (Ipomoea batatas L.), and paddy rice (Oryza sativa L.) are agronomically significant. Active expressions of the di-nitrogenase reductase-encoded gene (nifH) phylogenetically similar to those of Bradyrhizobium spp. and Azorhizobium sp. were abundantly found in the nitrogen-fixing sugarcane stems, sweet potato stems, and storage tubers. Setaria viridis, as well as Setaria italica (foxtail millet), is capable of securing a significant amount of fixed nitrogen from associations with Azospirillum brasilense [106,107]. Other promising associations include Azoarcus sp. strain BH72 and Kallar grass and Klebsiella pneumoniae and wheat [108]. A rhizosphere-associated nitrogen fixation can occur in three ways. First, rhizobia employ "crack entry" (a lack of Nod ABC genes, which results in a Nod factor-independent infection process [52,109,110] and invades xylem parenchyma tissues via cortical cells [111] in cut sugarcane stems [112] and sweet potato tuber [113]). Second, under low-oxygen level or micro-aerobic conditions, rhizobia may show free-living nitrogen fixation; for instance, Bradyrhizobium spp., nodulates Aeschynomene and Parasponia, Azorhizobium caulinodans, nodulates Sesbania rostrate, and Burkholderia, nodulates Mimosa, and all these rhizobia are capable of fixing nitrogen without a host plant under low-oxygen conditions [114-119]. Third, hormones of rhizobia origin that promote the growth of the host plant in accordance with fixed $\mathrm{N}$ acquisition; for instance, endophytic rhizobia promoting plant growth [64].

\subsubsection{Bacterial Nitrogen Fixation in Sugarcane}

Beijerinckia sp. from the rhizosphere of sugarcane was first isolated and observed in EMBRAPA Agrobiologia, Brazil [120]. The expression of nitrogenase nifH genes was examined by growing sugarcane cut-stems in Japan soils for 50 and 100 days by means of reverse transcription-polymerase 
chain reaction (RT-PCR) and the sequencing of nifH (encoding nitrogenase iron protein) nucleotides [112]. In that study, nifH sequences showed similarities with Bradyrhizobium spp. and Azorhizobium caulinodans, which suggested that the propagation of these nifH carrying Bradyrhizobium spp. may be a key factor in the endophytic nitrogen-fixation in the free-living state.

\subsubsection{Bacterial Nitrogen Fixation in Sweet Potato}

In growing sweet potato (Ipomoea batatas L.), farmers use relatively infertile soil and apply a small dosage of chemical fertilizers [121,122]. Azospirillum sp. was first identified in fibrous roots and storage root peels of sweet potato, and in the same study, additional investigations also indicated a high input of total nitrogen in sweet potato stems and tubers by endophytic Bradyrhizobium spp. [121]. In recent years, an isolated endophytic diazotroph, Bradyrhizobium sp. strain AT1 [113] showed a nifH sequence similarity to Aeschynomene stem-nodulating Bradyrhizobium sp. ORS391 [123].

\subsubsection{Bacterial Nitrogen Fixation in Paddy Field}

Much higher nitrogenase activities in a paddy rice-soil system were detected compared to the paddy soil without rice plants and in an upland rice-soil system [124]. In flooded soil, the root-soil interface has been proposed as the nitrogen-fixing site and the bacteria sustaining such nitrogen fixation activity under dark in flooded conditions were thought to be heterotrophic diazotrophs such as Azotobacter and Clostridia [124,125]. Later, in long term repeated pot experiments at the IRRI (International Rice Research Institute) [126], nitrogen fixation by not only photosynthetic cyanobacteria but also consistently by the heterotrophic diazotrophs utilizing root secretions of carbonaceous origin in the rhizosphere was observed [127]. In addition, a positive nitrogen balance was calculated, suggesting significant atmospheric nitrogen input in paddy rice fields [128]. From nifD (a nitrogenase protein-encoded gene) segments from crude root DNA, cloned nifD genes similar to those of $\gamma$-proteobacteria (Azotobacter vinelandii) and $\alpha$-proteobacteria (Bradyrhizobium japonicum) were detected $[129,130]$.

\subsubsection{Maize Mucilage and Microbiota Association for Nitrogen Fixation}

A recent study carried out in nitrogen-depleted fields of Oaxaca, Mexico, demonstrated that the mucilage associated with the aerial roots of Sierra Mixe maize can aide a complex diazotrophic microbiome that can encode active nitrogenase, and the fixed nitrogen (29\% to $82 \%$ of the plant nitrogen was derived from atmospheric nitrogen) can efficiently travel from the nitrogen-fixing microbiota to host plants [131]. In maize, aerial roots are known for enhancing nutrient and water uptake as well as an efficient gaseous exchange between plant tissue and the atmosphere [132-134].

\subsubsection{Bacterial Nitrogen Fixation in Switchgrass}

Switchgrass (Panicum virgatum L.) is a warm-season C4 grass. It is native to the tallgrass prairies of North America, and it has been well-studied for its use as a forage grass and more recently for its potential as a cellulosic biofuel $[135,136]$. In the absence of substantial nitrogen deposition or soil organic nitrogen unavailability, rhizobia-associated nitrogen-fixing is solely responsible for nitrogen supply and switchgrass can incorporate recently fixed nitrogen into its tissues $[137,138]$ and diverse communities of nitrogen-fixing bacteria are present in switchgrass rhizospheres such as Burkholderia spp., and Ralstonia taiwanensis of beta-proteobacteria have been found in the tissues of switchgrass which are known to form root nodules on host plants of Mimosa [139].

\section{Current Strategies and Tools for Engineering Symbiotic Nitrogen Fixation in Non-Legumes}

Although symbiotic nitrogen fixation is largely limited to legumes, there is an array of microorganisms, including some diazotrophs that inhabit the rhizosphere of other crop plants, which have been shown to enhance plant growth. The mechanisms involved in plants and microbes that lead to the formation and function of symbioses will help us in transferring these traits and processes 
to non-leguminous crops, especially in cereals. Advanced understanding of BNF, bacterial association with non-leguminous plants, and the microbial community composition of the rhizosphere population have led to several future research ideas for scientists; for instance, engineering non legume plants to nodulate and establish symbiotic nitrogen fixation, and the formulation of new associations between nitrogen-fixing microorganisms and crop plants $[140,141]$. Studies of evolutionary genomics suggest that relatively few genetic elements are needed to bestow nitrogen-fixation capabilities from legume to non-legume plants [142]. Transferring nitrogenase to plants requires the concatemerization of bacterial genetic units to create a minimum set of three genes [143]. The introduction of nitrogenase-encoding bacterial nif genes into non-legumes is challenging due to the complex nature of nitrogenase biosynthesis and the extreme sensitivity of nitrogenase to the presence of oxygen. Extensive genetic and biochemical studies have identified the common core set of genes/gene products required for functional nitrogenase biosynthesis [144].

In addition, potential subcellular (micro-pockets of air) low-oxygen environments offered via plastids and mitochondria to express active nitrogenase in plants making this engineering strategy feasible [145]. Although the nitrogen-fixing symbiosis is restricted to legumes, several components of the legume symbiotic signaling (SYM) pathway also play a role in the arbuscular mycorrhizal symbiosis. Many plants, including cereals, can form arbuscular mycorrhizal associations but lack the ability to form root nodules that can fix nitrogen. Like in legumes, the legume symbiotic signaling pathway (or SYM) also promotes the arbuscular mycorrhizal symbiosis. Since cereals contain the SYM pathway for arbuscular mycorrhizal associations, thus, this association can be engineered to perceive the rhizobial signaling molecules to activate this pathway, as well as by engineering its outputs of activation into an oxygen-limited nodule-like root organ for nitrogen fixation [64]. Recent phylogenomic studies suggest that a small set of genes could convert a species in association with arbuscular mycorrhizal fungi into a nitrogen-fixing symbiont $[146,147]$.

In cereal crops, mitochondria and chloroplasts ("nitroplast") [38] in plant cells are envisioned as suitable sites for performing the high energy-requiring nitrogenase enzyme production; however, a challenge for this approach would be the oxygen evolved by chloroplasts during photosynthesis that may be detrimental for the formation of the nitrogenase enzyme complex. A possible solution could be the temporal separation of photosynthesis and nitrogen fixation, which means the expression of nif gene only to dark periods (nights) or only in root systems (non-photosynthetic parts of plants) [19]. Also, a carbon secretion based approach in which a specialized carbon source encourages enhanced competition for carbon among nitrogen-fixing populations can also be utilized to establish appropriate signals between cereal crops and nitrogen-fixing microbes for effective colonization [64].

Previous studies have reported the influence of novel nutritional resources in the selection of microbial populations in the rhizosphere $[83,148]$. For instance, pea root mucilage is the sole source of carbon for some Rhizobium sp., Burkholderia sp., and Pseudomonas sp. [149]. Pursuing this "biased rhizosphere" approach to favor the growth of an introduced diazotroph which is able to use the novel rhizodeposition will involve the identification of appropriate plant and bacterial signals, receptors, and target genes [150]. Although transferring nitrogen fixation traits to crops beyond legumes has complex engineering problems, especially in the case of cereals, however, they might restructure the way cereal crops are grown. Even a small increase in available nitrogen in these self-supported nitrogen-fixing cereals will enable a substantial yield increase in the low-input farming systems of developing countries [151]. Moreover, in eukaryotes, some components of nitrogenase enzyme, for instance, active dinitrogenase reducatase can be expressed by mitochondrial targeting in yeast or plastid-targeting strategies in tobacco $[69,152,153]$. There is even an effort to synthesize an entire eukaryotic genome (Yeast 2.0). This expression of dinitrogenase in yeasts has important implications, especially for efficient nutrient uptake such as phosphate in cereal crop root habitats [131,154].

Opine molecules produced by transgenic plants are known to boost their rhizosphere with opine catabolizing bacteria; however, there is a risk of populating the rhizosphere with chemical compounds originating from pathogenic organisms $[82,83,148]$. Rhizopines are a rare group of 
compounds produced by a few species of rhizobia inside legume nodules and are exuded into the rhizosphere; namely, scyllo-inosamine 1 (SIA) and 3-O-methyl-scyllo-inosamine 2 (3-O-MSI) are believed to be suitable for ideal chemical signaling in the realm of trans-kingdom signaling between plants and rhizosphere bacteria, although engineering rhizopine-producing plants have not seen much success [155-158]. Rhizopines serves as the energy source (carbon and nitrogen) for Rhizobia and the gene responsible for rhizopine synthesis is (mosABC) and catabolism is (mocCABRDEF), which have been identified in the wild-type rhizobium Sinorhizobium meliloti L5-30 [159,160]. In the continued efforts in rhizosphere engineering of cereal crops, a recent study has successfully transferred the rhizopine biosynthesis genes into Hordeum vulgare (barley) [161]

\section{Conclusions}

Biological nitrogen fixation in plants can be a sustainable source of nitrogen and may divert our current dependence on industrial nitrogen production. This is especially true for food production in the developed world where agricultural production is still based on higher-yielding varieties and hybrids but with a simultaneous increase in inorganic nitrogen application. Not all the applied nitrogen in agricultural production is taken up by plants and the unused nitrogen has negative impacts on the environment, extending from eutrophication in nearby water bodies if the excess nitrogen is washed up by rainfall or surface runoff or nitrate poisoning in livestock. Future research should be focused on the efficient and strategic use of nitrogen-fixing legume plants, the use of higher legume plants such as Pongamia pinnata, in planned agroforestry, selecting highly competitive inoculants, and the use of non-legumes for nitrogen fixation. Artificial symbioses, associative nitrogen fixation in non-legume plants, especially in cereals such as rice, wheat, maize, targeted or biased rhizosphere, and understanding of endosymbiotic and endophytic nitrogen fixation with non-legume plants are some of the approaches that should be investigated to a greater extent.

Author Contributions: Conceptualization: K.M. and A.M.; Writing original draft preparation: K.M., S.M. and R.I.; Reviewing and Editing: K.M. and A.M.; Supervision: A.M.; Funding Acquisition: A.M. All authors have read and agreed to the published version of the manuscript.

Funding: Funding provided by The Center for Bioenergy Innovation a U.S. Department of Energy Research Center supported by the Office of Biological and Environmental Research in the DOE Office of Science.

Conflicts of Interest: The authors declare no conflict of interest.

\section{References}

1. Ney, L.; Franklin, D.; Mahmud, K.; Cabrera, M.; Hancock, D.; Habteselassie, M.; Newcomer, Q.; Fatzinger, B. Rebuilding Soil Ecosystems for Improved Productivity in Biosolarized Soils. Int. J. Agron. 2019, 2019, 5827585. [CrossRef]

2. Vitousek, P.; Howarth, R. Nitrogen limitation on land and in the sea: How can it occur? Biogeochemistry 1991, 13, 87-115. [CrossRef]

3. Hedin, L.O.; Brookshire, E.J.; Menge, D.N.; Barron, A.R. The Nitrogen Paradox in Tropical Forest Ecosystems. Annu. Rev. Ecol. Evol. Syst. 2009, 40, 613-635. [CrossRef]

4. Galloway, J.N.; Townsend, A.R.; Erisman, J.W.; Bekunda, M.; Cai, Z.; Freney, J.R.; Martinelli, L.A.; Seitzinger, S.P.; Sutton, M.A. Transformation of the Nitrogen Cycle: Recent Trends, Questions, and Potential Solutions. Science 2008, 320, 889-892. [CrossRef] [PubMed]

5. Vitousek, P.M.; Menge, D.N.L.; Reed, S.C.; Cleveland, C.C. Biological nitrogen fixation: rates, patterns and ecological controls in terrestrial ecosystems. Philos. Trans. R. Soc. B: Boil. Sci. 2013, 368, 20130119. [CrossRef] [PubMed]

6. Dobermann, A. Nutrient use efficiency-Measurement and management. In Proceedings of the International Fertilizer Industry Association, Brussels, Belgium, 7-9 March 2007; pp. 1-22.

7. Westhoff, P. The economics of biological nitrogen fixation in the global economy. Agron. Monogr. 2009, 52, 309-328. 
8. Santi, C.; Bogusz, D.; Franche, C. Biological nitrogen fixation in non-legume plants. Ann. Bot. 2013, 111, 743-767. [CrossRef]

9. Da Silva, J.G.; Serra, G.E.; Moreira, J.R.; Conçalves, J.C.; Goldemberg, J. Energy Balance for Ethyl Alcohol Production from Crops. Science 1978, 201, 903-906. [CrossRef]

10. Sulieman, S.; Tran, L. Legume Nitrogen Fixation in a Changing Environment; Springer International Publishing: Cham, Switzerland, 2016.

11. Lindström, K.; Murwira, M.; Willems, A.; Altier, N. The biodiversity of beneficial microbe-host mutualism: the case of rhizobia. Res. Microbiol. 2010, 161, 453-463. [CrossRef] [PubMed]

12. Dahal, S.; Franklin, D.H.; Cabrera, M.L.; Hancock, D.W.; Stewart, L.; Ney, L.C.; Subedi, A.; Mahmud, K. Spatial Distribution of Inorganic Nitrogen in Pastures as Affected by Management, Landscape, and Cattle Locus. J. Environ. Qual. 2018, 47, 1468-1477. [CrossRef] [PubMed]

13. Franche, C.; Lindström, K.; Elmerich, C. Nitrogen-fixing bacteria associated with leguminous and non-leguminous plants. Plant Soil 2009, 321, 35-59. [CrossRef]

14. Lam, H.-M.; Coschigano, K.T.; Oliveira, I.C.; Melo-Oliveira, R.; Coruzzi, G.M. The molecular-genetics of nitrogen assimilation into amino acids in higher plants. Annu. Rev. Plant Boil. 1996, 47, 569-593. [CrossRef] [PubMed]

15. Graham, P.H. Stress tolerance in Rhizobium and Bradyrhizobium, and nodulation under adverse soil conditions. Can. J. Microbiol. 1992, 38, 475-484. [CrossRef]

16. Peoples, M.B.; Brockwell, J.; Herridge, D.F.; Rochester, I.J.; Alves, B.J.R.; Urquiaga, S.; Boddey, R.M.; Dakora, F.D.; Bhattarai, S.; Maskey, S.L.; et al. The contributions of nitrogen-fixing crop legumes to the productivity of agricultural systems. Symbiosis 2009, 48, 1-17. [CrossRef]

17. Ramírez-Puebla, S.T.; Ormeño-Orrillo, E.; Rogel, M.A.; López-Guerrero, M.G.; López-López, A.; Martínez-Romero, J.; Negrete-Yankelevich, S.; Martínez-Romero, E. La diversidad de rizobios nativos de México a la luz de la genómica. Rev. Mex. Biodivers. 2019, 90, 902681. [CrossRef]

18. Fustec, J.; Lesuffleur, F.; Mahieu, S.; Cliquet, J.-B. Nitrogen rhizodeposition of legumes. A review. Agron. Sustain. Dev. 2010, 30, 57-66. [CrossRef]

19. Rosenblueth, M.; Ormeño-Orrillo, E.; López-López, A.; Rogel, M.A.; Reyes-Hernández, B.J.; Martínez-Romero, J.C.; Reddy, P.M.; Martínez-Romero, E. Nitrogen Fixation in Cereals. Front. Microbiol. 2018, 9, 9. [CrossRef]

20. Morris, J.J.; Schniter, E.J. Black Queen markets: Commensalism, dependency, and the evolution of cooperative specialization in human society. J. Bioecon. 2018, 20, 69-105. [CrossRef]

21. Peix, A.; Ramírez-Bahena, M.H.; Velázquez, E.; Bedmar, E.J. Bacterial associations with legumes. Crit. Rev. Plant Sci. 2015, 34, 17-42. [CrossRef]

22. Graham, P.H.; Vance, C.P. Legumes: Importance and constraints to greater use. Plant Physiol. 2003, 131, 872-877. [CrossRef]

23. King, C.A.; Purcell, L.C. Inhibition of N2 fixation in soybean is associated with elevated ureides and amino acids. Plant Physiol. 2005, 137, 1389-1396. [CrossRef] [PubMed]

24. Liu, Y.; Wu, L.; Baddeley, J.A.; Watson, C.A. Models of Biological Nitrogen Fixation of Legumes. In Sustainable Agriculture; Springer: Dordrecht, The Netherlands, 2011; Volume 2, pp. 883-905.

25. Purcell, L.C.; Serraj, R.; De Silva, M.; Sinclair, T.R.; Bona, S. Ureide concentration of field-grown soybean in response to drought and the relationship to nitrogen fixation. J. Plant Nutr. 1998, 21, 949-966. [CrossRef]

26. Zahran, H.H. Rhizobium-legume symbiosis and nitrogen fixation under severe conditions and in an arid climate. Microbiol. Mol. Biol. Rev. 1999, 63, 968-989. [CrossRef] [PubMed]

27. Schultze, M.; Kondorosi, A.J. Regulation of symbiotic root nodule development. Annu. Rev. Genet. 1998, 32, 33-57. [CrossRef]

28. Oldroyd, G.E.; Downie, J.A. Coordinating nodule morphogenesis with rhizobial infection in legumes. Annu. Rev. Plant Biol. 2008, 59, 519-546. [CrossRef]

29. Desbrosses, G.J.; Stougaard, J. Root nodulation: A paradigm for how plant-microbe symbiosis influences host developmental pathways. Cell Host Microbe 2011, 10, 348-358. [CrossRef]

30. Burén, S.; Rubio, L.M. State of the art in eukaryotic nitrogenase engineering. FEMS Microbiol. Lett. $2017,365$. [CrossRef]

31. Yates, M.; Jones, C. Respiration and Nitrogen Fixation in Azotobacter. In Advances in Microbial Physiology; Elsevier BV: Amsterdam, The Netherlands, 1974; Volume 11, pp. 97-135. 
32. Poole, R.K.; Hill, S. Respiratory protection of nitrogenase activity in Azotobacter vinelandii-Roles of the terminal oxidases. Biosci. Rep. 1997, 17, 303-317. [CrossRef]

33. Bulen, W.; LeComte, J.J. The nitrogenase system from Azotobacter: Two-enzyme requirement for N2 reduction, ATP-dependent H2 evolution, and ATP hydrolysis. Proc. Natl. Acad. Sci. USA 1966, 56, 979. [CrossRef]

34. Bishop, P.E.; Joerger, R.D. Genetics and molecular biology of alternative nitrogen fixation systems. Annu. Rev. Plant Biol. 1990, 41, 109-125. [CrossRef]

35. Shah, V.K.; Brill, W.J. Isolation of an iron-molybdenum cofactor from nitrogenase. Proc. Natl. Acad. Sci. USA 1977, 74, 3249-3253. [CrossRef] [PubMed]

36. Dos Santos, P.C.; Fang, Z.; Mason, S.W.; Setubal, J.C.; Dixon, R. Distribution of nitrogen fixation and nitrogenase-like sequences amongst microbial genomes. BMC Genom. 2012, 13, 162. [CrossRef] [PubMed]

37. McGlynn, S.E.; Boyd, E.S.; Peters, J.W.; Orphan, V.J. Classifying the metal dependence of uncharacterized nitrogenases. Front. Microbiol. 2013, 3, 419. [CrossRef] [PubMed]

38. Biswas, B.; Gresshoff, P.M. The role of symbiotic nitrogen fixation in sustainable production of biofuels. Int. J. Mol. Sci. 2014, 15, 7380-7397. [CrossRef] [PubMed]

39. Spaink, H.P. Root nodulation and infection factors produced by rhizobial bacteria. Annu. Rev. Microbiol. 2000, 54, 257-288. [CrossRef] [PubMed]

40. Redmond, J.W.; Batley, M.; Djordjevic, M.A.; Innes, R.W.; Kuempel, P.L.; Rolfe, B.G. Flavones induce expression of nodulation genes in Rhizobium. Nature 1986, 323, 632-635. [CrossRef]

41. Caetano-Anollés, G.; Gresshoff, P.M. Plant genetic control of nodulation. Annu. Rev. Microbiol. 1991, 45, 345-382. [CrossRef]

42. Denarie, J.; Debelle, F.; Prome, J.-C. Rhizobium lipo-chitooligosaccharide nodulation factors: Signaling molecules mediating recognition and morphogenesis. Annu. Rev. Biochem. 1996, 65, 503-535. [CrossRef]

43. Szczyglowski, K.; Shaw, R.S.; Wopereis, J.; Copeland, S.; Hamburger, D.; Kasiborski, B.; Dazzo, F.B.; De Bruijn, F.J. Nodule Organogenesis and Symbiotic Mutants of the Model Legume Lotus japonicus. Mol. Plant-Microbe Interact. 1998, 11, 684-697. [CrossRef]

44. Calvert, H.E.; Pence, M.K.; Pierce, M.; Malik, N.S.A.; Bauer, W.D. Anatomical analysis of the development and distribution of Rhizobium infections in soybean roots. Can. J. Bot. 1984, 62, 2375-2384. [CrossRef]

45. Mathews, A.; Carroll, B.; Gresshoff, P.J.P. Development of Bradyrhizobium infections in supernodulating and non-nodulating mutants of soybean (Glycine max [L.] Merrill). Protoplasma 1989, 150, 40-47. [CrossRef]

46. Gresshoff, P.M.; Delves, A.C. Plant genetic approaches to symbiotic nodulation and nitrogen fixation in legumes. In Plant Gene Research; Springer Science and Business Media LLC: Vienna, Austria, 1986; pp. 159-206.

47. Timmers, A.; Auriac, M.-C.; Truchet, G.J.D. Refined analysis of early symbiotic steps of the Rhizobium-Medicago interaction in relationship with microtubular cytoskeleton rearrangements. Development 1999, 126, 3617-3628. [PubMed]

48. Wopereis, J.; Pajuelo, E.; Dazzo, F.B.; Jiang, Q.; Gresshoff, P.M.; De Bruijn, F.J.; Stougaard, J.; Szczyglowski, K. Short root mutant of Lotus japonicus with a dramatically altered symbiotic phenotype. Plant J. 2000, 23, 97-114. [CrossRef] [PubMed]

49. Newcomb, W.; Sippell, D.; Peterson, R.J. The early morphogenesis of Glycine max and Pisum sativum root nodules. Can. J. Bot. 1979, 57, 2603-2616. [CrossRef]

50. Rolfe, B.G.; Gresshoff, P.J.; Biology, P.M. Genetic analysis of legume nodule initiation. Annu. Rev. Plant Physiol. Plant Mol. Biol. 1988, 39, 297-319. [CrossRef]

51. Galibert, F.; Finan, T.M.; Long, S.R.; Pühler, A.; Abola, P.; Ampe, F.; Barloy-Hubler, F.; Barnett, M.J.; Becker, A.; Boistard, P.; et al. The Composite Genome of the Legume Symbiont Sinorhizobium meliloti. Science 2001, 293, 668-672. [CrossRef]

52. Giraud, E.; Moulin, L.; Vallenet, D.; Barbe, V.; Cytryn, E.; Avarre, J.-C.; Jaubert, M.; Simon, D.; Cartieaux, F.; Prin, Y.; et al. Legumes Symbioses: Absence of Nod Genes in Photosynthetic Bradyrhizobia. Science 2007, 316, 1307-1312. [CrossRef]

53. Kaneko, T.; Nakamura, Y.; Sato, S.; Asamizu, E.; Kato, T.; Sasamoto, S.; Watanabe, A.; Idesawa, K.; Ishikawa, A.; Kawashima, K.; et al. Complete genome structure of the nitrogen-fixing symbiotic bacterium Mesorhizobium loti. DNA Res. 2000, 7, 331-338. [CrossRef]

54. Adams, T.H.; McClung, C.R.; Chelm, B.K. Physical organization of the Bradyrhizobium japonicum nitrogenase gene region. J. Bacteriol. 1984, 159, 857-862. [CrossRef] 
55. Jacobson, M.R.; Brigle, K.E.; Bennett, L.T.; Setterquist, R.A.; Wilson, M.S.; Cash, V.L.; Beynon, J.; Newton, W.E.; Dean, D.R. Physical and genetic map of the major nif gene cluster from Azotobacter vinelandii. J. Bacteriol. 1989, 171, 1017-1027. [CrossRef]

56. Pedrosa, F.; Teixeira, K.; Machado, I.; Steffens, M.; Klassen, G.; Benelli, E.; Machado, H.; Funayama, S.; Rigo, L.; Ishida, M.; et al. Structural organization and regulation of the nif genes of Herbaspirillum seropedicae. Soil Boil. Biochem. 1997, 29, 843-846. [CrossRef]

57. Yan, Y.; Yang, J.; Dou, Y.; Chen, M.; Ping, S.; Peng, J.; Lu, W.; Zhang, W.; Yao, Z.; Li, H.; et al. Nitrogen fixation island and rhizosphere competence traits in the genome of root-associated Pseudomonas stutzeri A1501. Proc. Natl. Acad. Sci. USA 2008, 105, 7564-7569. [CrossRef] [PubMed]

58. Masepohl, B.; Drepper, T.; Paschen, A.; Gross, S.; Pawlowski, A.; Raabe, K.; Riedel, K.-U.; Klipp, W. Regulation of nitrogen fixation in the phototrophic purple bacterium Rhodobacter capsulatus. J. Mol. Microbiol. Biotechnol. 2002, 4, 243-248. [PubMed]

59. Lee, S.; Reth, A.; Meletzus, D.; Sevilla, M.; Kennedy, C. Characterization of a Major Cluster of nif,fix, and Associated Genes in a Sugarcane Endophyte,Acetobacter diazotrophicus. J. Bacteriol. 2000, 182, 7088-7091. [CrossRef]

60. Kallas, T.; Coursin, T.; Rippka, R.J. Different organization of nif genes in nonheterocystous and heterocystous cyanobacteria. Plant Mol. Biol. 1985, 5, 321-329. [CrossRef]

61. Earl, C.; Ronson, C.; Ausubel, F.J. Genetic and structural analysis of the Rhizobium meliloti fixA, fixB, fixC, and fixX genes. J. Bacteriol. 1987, 169, 1127-1136. [CrossRef]

62. Edgren, T.; Nordlund, S.J. The fix $A B C X$ genes in Rhodospirillum rubrum encode a putative membrane complex participating in electron transfer to nitrogenase. J. Bacteriol. 2004, 186, 2052-2060. [CrossRef]

63. Cárdenas, L.; Domínguez, J.; Quinto, C.; López-Lara, I.M.; Lugtenberg, B.J.; Spaink, H.P.; Rademaker, G.J.; Haverkamp, J.; Thomas-Oates, J.E. Isolation, chemical structures and biological activity of the lipo-chitin oligosaccharide nodulation signals from Rhizobium etli. Plant Mol. Boil. 1995, 29, 453-464. [CrossRef]

64. Mus, F.; Crook, M.B.; Garcia, K.; Costas, A.G.; Geddes, B.A.; Kouri, E.D.; Paramasivan, P.; Ryu, M.-H.; Oldroyd, G.E.D.; Poole, P.S.; et al. Symbiotic Nitrogen Fixation and the Challenges to Its Extension to Nonlegumes. Appl. Environ. Microbiol. 2016, 82, 3698-3710. [CrossRef]

65. Perret, X.; Staehelin, C.; Broughton, W.J. Molecular basis of symbiotic promiscuity. Microbiol. Mol. Biol. Rev. 2000, 64, 180-201. [CrossRef]

66. Kamfwa, K.; Cichy, K.A.; Kelly, J.D. Identification of quantitative trait loci for symbiotic nitrogen fixation in common bean. Theor. Appl. Genet. 2019, 132, 1375-1387. [CrossRef] [PubMed]

67. Ohlson, E.W.; Seido, S.L.; Mohammed, S.; Santos, C.A.F.; Timko, M.P. QTL Mapping of Ineffective Nodulation and Nitrogen Utilization-Related Traits in the IC-1 Mutant of Cowpea. Crop Sci. 2018, 58, 264-272. [CrossRef]

68. Tominaga, A.; Gondo, T.; Akashi, R.; Zheng, S.H.; Arima, S.; Suzuki, A. Quantitative trait locus analysis of symbiotic nitrogen fixation activity in the model legume Lotus japonicus. J. Plant Res. 2012, 125, 395-406. [CrossRef] [PubMed]

69. Yang, J.; Xie, X.; Yang, M.; Dixon, R.; Wang, Y.-P. Modular electron-transport chains from eukaryotic organelles function to support nitrogenase activity. Proc. Natl. Acad. Sci. USA 2017, 114, E2460-E2465. [CrossRef]

70. Muñoz, N.; Qi, X.; Li, M.-W.; Xie, M.; Gao, Y.; Cheung, M.-Y.; Wong, F.-L.; Lam, H.-M. Improvement in nitrogen fixation capacity could be part of the domestication process in soybean. Heredity 2016, 117, 84-93. [CrossRef]

71. Li, X.; Zheng, J.; Yang, Y.; Liao, H. INCREASING NODULE SIZE1 Expression Is Required for Normal Rhizobial Symbiosis and Nodule Development. Plant Physiol. 2018, 178, 1233-1248. [CrossRef]

72. Jones, D.L.; Nguyen, C.; Finlay, R.D. Carbon flow in the rhizosphere: carbon trading at the soil-root interface. Plant Soil 2009, 321, 5-33. [CrossRef]

73. Günter, N.; Volker, R. The release of root exudates as affected by the plant physiological status. In The Rhizophere: Biochemistry and Organic Substances at the Soilplant Interface; Pinton, R., Varanini, Z., Nannipieri, P., Eds.; CRC Press: Boca Raton, FL, USA, 2007; pp. 23-72.

74. Turner, T.R.; James, E.K.; Poole, P.S. The plant microbiome. Genome Biol. 2013, 14, 209. [CrossRef]

75. Turner, T.R.; Ramakrishnan, K.; Walshaw, J.; Heavens, D.; Alston, M.; Swarbreck, D.; Osbourn, A.; Grant, A.; Poole, P.S. Comparative metatranscriptomics reveals kingdom level changes in the rhizosphere microbiome of plants. ISME J. 2013, 7, 2248-2258. [CrossRef] 
76. Baetz, U.; Martinoia, E.J. Root exudates: The hidden part of plant defense. Trends Plant Sci. 2014, 19, 90-98. [CrossRef]

77. Kamilova, F.; Kravchenko, L.V.; Shaposhnikov, A.I.; Azarova, T.; Makarova, N.; Lugtenberg, B. Organic Acids, Sugars, and 1 -Tryptophane in Exudates of Vegetables Growing on Stonewool and Their Effects on Activities of Rhizosphere Bacteria. Mol. Plant-Microbe Interact. 2006, 19, 250-256. [CrossRef]

78. Kamilova, F.; Validov, S.; Azarova, T.; Mulders, I.; Lugtenberg, B. Enrichment for enhanced competitive plant root tip colonizers selects for a new class of biocontrol bacteria. Environ. Microbiol. 2005, 7, 1809-1817. [CrossRef] [PubMed]

79. Van Egeraat, A. The possible role of homoserine in the development of Rhizobium leguminosarum in the rhizosphere of pea seedlings. Plant Soil 1975, 42, 381-386. [CrossRef]

80. Vanderlinde, E.M.; Hynes, M.F.; Yost, C.K. Homoserine catabolism by Rhizobium leguminosarum bv. viciae 3841 requires a plasmid-borne gene cluster that also affects competitiveness for nodulation. Environ. Microbiol. 2014, 16, 205-217. [PubMed]

81. Fan, J.; Crooks, C.; Creissen, G.; Hill, L.; Fairhurst, S.; Doerner, P.; Lamb, C. Pseudomonas sax Genes Overcome Aliphatic Isothiocyanate-Mediated Non-Host Resistance in Arabidopsis. Science 2011, 331, 1185-1188. [CrossRef] [PubMed]

82. Mondy, S.; Lenglet, A.; Libanga, C.; Ratet, P.; Faure, D.; Dessaux, Y.; Beury-Cirou, A. An increasing opine carbon bias in artificial exudation systems and genetically modified plant rhizospheres leads to an increasing reshaping of bacterial populations. Mol. Ecol. 2014, 23, 4846-4861. [CrossRef] [PubMed]

83. Oger, P.; Petit, A.; Dessaux, Y.J. Genetically engineered plants producing opines alter their biological environment. Nat. Biotechnol. 1997, 15, 369. [CrossRef]

84. Mayer, J.; Buegger, F.; Jensen, E.S.; Schloter, M.; Heß, J. Estimating N rhizodeposition of grain legumes using a $15 \mathrm{~N}$ in situ stem labelling method. Soil Boil. Biochem. 2003, 35, 21-28. [CrossRef]

85. McNeill, A.; Fillery, I.J.P. Field measurement of lupin belowground nitrogen accumulation and recovery in the subsequent cereal-soil system in a semi-arid Mediterranean-type climate. Plant Soil 2008, 302, 297-316. [CrossRef]

86. Ta, T.; Faris, M.J.P. Effects of environmental conditions on the fixation and transfer of nitrogen from alfalfa to associated timothy. Plant Soil 1988, 107, 25-30. [CrossRef]

87. Bohlool, B.B.; Ladha, J.K.; Garrity, D.P.; George, T. Biological nitrogen fixation for sustainable agriculture: A perspective. Plant Soil 1992, 141,1-11. [CrossRef]

88. Unkovich, M.J.; Baldock, J.; Peoples, M.B. Prospects and problems of simple linear models for estimating symbiotic N2 fixation by crop and pasture legumes. Plant Soil 2010, 329, 75-89. [CrossRef]

89. Cornish, P.S.; Baginska, B.; Kuczera, G.; Jones, D.; Mohammad, A. Measuring the effects of land use and land management on river water quality. In Proceedings of the 8th Australian Agronomy Conference, Toowoomba, Australia, 30 January-2 February 1996.

90. Khan, W.D.F.; Peoples, M.B.; Herridge, D.F. Quantifying below-ground nitrogen of legumes. Plant Soil 2002, 245, 327-334. [CrossRef]

91. Van Sambeek, J.; Ponder, F.; Rietveld, W. Legumes increase growth and alter foliar nutrient levels of black walnut saplings. For. Ecol. Manag. 1986, 17, 159-167. [CrossRef]

92. Van Sambeek, J.; Garrett, H. Ground Cover Management in Walnut and Other Hardwood Plantings. In Proceedings of the 6th Walnut Council Research Symposium, St. Paul, MN, USA, 25-28 July 2004; pp. 85-100.

93. Zapata, F.; Danso, S.K.A.; Hardarson, G.; Fried, M. Time Course of Nitrogen Fixation in Field-Grown Soybean Using Nitrogen-15 Methodology1. Agron. J. 1987, 79, 172-176. [CrossRef]

94. Frame, J.; Laidlaw, A.J. Prospects for temperate forage legumes. In Grasslands: Developments, Opportunities, Perspectives; Reynolds, S.G., Frame, J., Eds.; Science Publishers, Inc.: Enfield, NH, USA, 2005; pp. 1-28.

95. Adhikari, L.; Missaoui, A.M. Nodulation response to molybdenum supplementation in alfalfa and its correlation with root and shoot growth in low pH soil. J. Plant Nutr. 2017, 40, 2290-2302. [CrossRef]

96. Loreau, M.; Hector, A.J.N. Partitioning selection and complementarity in biodiversity experiments. Nature 2001, 412, 72. [CrossRef]

97. Heichel, G.; Barnes, D.; Vance, C.J. Nitrogen Fixation of Alfalfa in the Seeding Year. Crop Sci. 1981, 21, 330-335. [CrossRef] 
98. Arpiwi, N.L.; Yan, G.; Barbour, E.L.; Plummer, J.A. Genetic diversity, seed traits and salinity tolerance of Millettia pinnata (L.) Panigrahi, a biodiesel tree. Genet. Resour. Crop Evol. 2013, 60, 677-692. [CrossRef]

99. Kesari, V.; Ramesh, A.M.; Rangan, L.J. Rhizobium pongamiae sp. nov. from root nodules of Pongamia pinnata. BioMed Res. Int. 2013. [CrossRef]

100. Rasul, A.; Amalraj, E.L.D.; Praveen Kumar, G.; Grover, M.; Venkateswarlu, B. Characterization of rhizobial isolates nodulating Millettia pinnata in India. FEMS Microbiol. Lett. 2012, 336, 148-158. [CrossRef]

101. Samuel, S.; Scott, P.T.; Gresshoff, P.M. Nodulation in the legume biofuel feedstock tree Pongamia pinnata. Agric. Res. 2013, 2, 207-214. [CrossRef]

102. James, E.J. Nitrogen fixation in endophytic and associative symbiosis. Field Crops Res. 2000, 65, $197-209$. [CrossRef]

103. White, J.F.; Crawford, H.; Torres, M.S.; Mattera, R.; Irizarry, I.; Bergen, M. A proposed mechanism for nitrogen acquisition by grass seedlings through oxidation of symbiotic bacteria. Symbiosis 2012, 57, 161-171. [CrossRef] [PubMed]

104. Barber, D.; Lynch, J.J. Microbial growth in the rhizosphere. Soil Biol. Biochem. 1977, 9, 305-308. [CrossRef]

105. Delwiche, C.; Wijler, J.J. Non-symbiotic nitrogen fixation in soil. Plant Soil 1956, 7, 113-129. [CrossRef]

106. Okon, Y.; Heytler, P.; Hardy, R.J. N2 fixation by Azospirillum brasilense and its incorporation into host Setaria italica. Appl. Environ. Microbiol. 1983, 46, 694-697. [CrossRef]

107. Pankievicz, V.C.S.; Amaral, F.P.D.; Santos, K.F.D.N.; Agtuca, B.; Xu, Y.; Schueller, M.J.; Arisi, A.C.M.; Steffens, M.B.; De Souza, E.M.; Pedrosa, F.O.; et al. Robust biological nitrogen fixation in a model grass-bacterial association. Plant J. 2015, 81, 907-919. [CrossRef]

108. Iniguez, A.L.; Dong, Y.; Triplett, E.W. Nitrogen fixation in wheat provided by Klebsiella pneumoniae 342. Mol. Plant-Microbe Interact. 2004, 17, 1078-1085. [CrossRef]

109. Bonaldi, K.; Gourion, B.; Fardoux, J.; Hannibal, L.; Cartieaux, F.; Boursot, M.; Vallenet, D.; Chaintreuil, C.; Prin, Y.; Nouwen, N.; et al. Large-Scale Transposon Mutagenesis of Photosynthetic Bradyrhizobium Sp. Strain ORS278 Reveals New Genetic Loci Putatively Important for Nod-Independent Symbiosis with Aeschynomene indica. Mol. Plant-Microbe Interact. 2010, 23, 760-770. [CrossRef]

110. Chaintreuil, C.; Arrighi, J.-F.; Giraud, E.; Miché, L.; Moulin, L.; Dreyfus, B.; Munive-Hernández, J.; Villegas-Hernandez, M.D.C.; Béna, G. Evolution of symbiosis in the legume genusAeschynomene. New Phytol. 2013, 200, 1247-1259. [CrossRef]

111. Chi, F.; Shen, S.-H.; Cheng, H.-P.; Jing, Y.-X.; Yanni, Y.G.; Dazzo, F.B. Ascending Migration of Endophytic Rhizobia, from Roots to Leaves, inside Rice Plants and Assessment of Benefits to Rice Growth Physiology. Appl. Environ. Microbiol. 2005, 71, 7271-7278. [CrossRef]

112. Thaweenut, N.; Hachisuka, Y.; Ando, S.; Yanagisawa, S.; Yoneyama, T. Two seasons' study on nifH gene expression and nitrogen fixation by diazotrophic endophytes in sugarcane (Saccharum spp. hybrids): Expression of nifH genes similar to those of rhizobia. Plant Soil 2011, 338, 435-449. [CrossRef]

113. Terakado-Tonooka, J.; Fujihara, S.; Ohwaki, Y. Possible contribution of Bradyrhizobium on nitrogen fixation in sweet potatoes. Plant Soil 2013, 367, 639-650. [CrossRef]

114. Alazard, D.J. Nitrogen fixation in pure culture by rhizobia isolated from stem nodules of tropical Aeschynomene species. FEMS Microbiol. Lett. 1990, 68, 177-182. [CrossRef]

115. Chen, W.M.; Moulin, L.; Bontemps, C.; Vandamme, P.; Béna, G.; Boivin-Masson, C. Legume symbiotic nitrogen fixation by $\beta$-proteobacteria is widespread in nature. J. Bacteriol. 2003, 185, 7266-7272. [CrossRef]

116. Dreyfus, B.; Elmerich, C.; Dommergues, Y.J. Free-living Rhizobium strain able to grow on N2 as the sole nitrogen source. Appl. Environ. Microbiol. 1983, 45, 711-713. [CrossRef]

117. Elliott, G.N.; Chen, W.M.; Chou, J.H.; Wang, H.C.; Sheu, S.Y.; Perin, L.; Reis, V.M.; Moulin, L.; Simon, M.F.; Bontemps, C.; et al. Burkholderia phymatum is a highly effective nitrogen-fixing symbiont of Mimosa spp. and fixes nitrogen ex planta. New Phytol. 2007, 173, 168-180.

118. Gebhardt, C.; Turner, G.L.; Gibson, A.H.; Dreyfus, B.L.; Bergersen, F.J. Nitrogen-fixing Growth in Continuous Culture of a Strain of Rhizobium sp. Isolated from Stem Nodules on Sesbania rostrata. Microbiology 1984, 130, 843-848. [CrossRef]

119. Mohapatra, S.S.; Bender, G.L.; Shine, J.; Rolfe, B.G.; Gresshoff, P.M. In vitro expression of nitrogenase activity in Parasponia-Rhizobium strain ANU 289. Arch. Microbiol. 1983, 134, 12-16. [CrossRef]

120. Dobereiner, J. Nitrogen-fixing bacteria of the genusBeijerinckia Derx in the rhizosphere of sugar cane. Plant Soil 1961, 15, 211-216. [CrossRef] 
121. Hill, W.A.; Bacon-Hill, P.; Crossman, S.M.; Stevens, C. Characterization of N2-fixing bacteria associated with sweet potato roots. Can. J. Microbiol. 1983, 29, 860-862. [CrossRef]

122. Yoneyama, T.; Terakado, J.; Masuda, T. Natural abundance of $15 \mathrm{~N}$ in sweet potato, pumpkin, sorghum and castor bean: possible input of N 2 -derived nitrogen in sweet potato. Boil. Fertil. Soils 1997, 26, 152-154. [CrossRef]

123. Nzoué, A.; Miché, L.; Klonowska, A.; Laguerre, G.; De Lajudie, P.; Moulin, L. Multilocus sequence analysis of bradyrhizobia isolated from Aeschynomene species in Senegal. Syst. Appl. Microbiol. 2009, 32, 400-412. [CrossRef]

124. Yoshida, T.; Ancajas, R.R. Nitrogen-Fixing Activity in Upland and Flooded Rice Fields. Soil Sci. Soc. Am. J. 1973, 37, 42-46. [CrossRef]

125. Kimura, M.; Panichsakpatana, S.; Wada, H.; Takai, Y. Influences of organic debris and rice root on the nitrogen fixation in the submerged soil. Soil Sci. Plant Nutr. 1979, 25, 637-640. [CrossRef]

126. App, A.A.; Watanabe, I.; Alexander, M.; Ventura, W.; Daez, C.; Santiago, T.; De Datta, S.K. Nonsymbiotic nitrogen fixation associated with the rice plant in flooded soils. Soil Sci. 1980, 130, 283-289. [CrossRef]

127. Yoneyama, T.; Terakado-Tonooka, J.; Minamisawa, K. Exploration of bacterial N2-fixation systems in association with soil-grown sugarcane, sweet potato, and paddy rice: a review and synthesis. Soil Sci. Plant Nutr. 2017, 63, 578-590. [CrossRef]

128. Ladha, J.K.; Tirol-Padre, A.; Reddy, C.K.; Cassman, K.G.; Verma, S.; Powlson, D.S.; Van Kessel, C.; Richter, D.D.B.; Chakraborty, D.; Pathak, H. Global nitrogen budgets in cereals: A 50-year assessment for maize, rice and wheat production systems. Sci. Rep. 2016, 6, 19355. [CrossRef]

129. Ueda, T.; Suga, Y.; Yahiro, N.; Matsuguchi, T. Remarkable N2-fixing bacterial diversity detected in rice roots by molecular evolutionary analysis of nifH gene sequences. J. Bacteriol. 1995, 177, 1414-1417. [CrossRef]

130. Ueda, T.; Suga, Y.; Yahiro, N.; Matsuguchi, T. Genetic diversity of N2-fixing bacteria associated with rice roots by molecular evolutionary analysis of a nifD library. Can. J. Microbiol. 1995, 41, 235-240. [CrossRef] [PubMed]

131. Van Deynze, A.; Zamora, P.; Delaux, P.-M.; Heitmann, C.; Jayaraman, D.; Rajasekar, S.; Graham, D.; Maeda, J.; Gibson, D.; Schwartz, K.D.; et al. Nitrogen fixation in a landrace of maize is supported by a mucilage-associated diazotrophic microbiota. PLoS Boil. 2018, 16, e2006352. [CrossRef] [PubMed]

132. Hochholdinger, F.; Woll, K.; Sauer, M.; Dembinsky, D. Genetic Dissection of Root Formation in Maize (Zea mays) Reveals Root-type Specific Developmental Programmes. Ann. Bot. 2004, 93, 359-368. [CrossRef]

133. Hoppe, D.; McCully, M.; Wenzel, C.J. The nodal roots of Zea: Their development in relation to structural features of the stem. Can. J. Bot. 1986, 64, 2524-2537. [CrossRef]

134. Li, Y.J.; Fu, Y.R.; Huang, J.G.; Wu, C.A.; Zheng, C.C. Transcript profiling during the early development of the maize brace root via Solexa sequencing. FEBS J. 2011, 278, 156-166. [CrossRef]

135. McLaughlin, S.B.; Kszos, L.A. Development of switchgrass (Panicum virgatum) as a bioenergy feedstock in the United States. Biomass Bioenergy 2005, 28, 515-535. [CrossRef]

136. Robertson, G.P.; Hamilton, S.K.; Barham, B.L.; Dale, B.E.; Izaurralde, R.C.; Jackson, R.D.; Landis, D.A.; Swinton, S.M.; Thelen, K.D.; Tiedje, J.M. Cellulosic biofuel contributions to a sustainable energy future: Choices and outcomes. Science 2017, 356, eaal2324. [CrossRef]

137. Morris, D.; Zuberer, D.; Weaver, R. Nitrogen fixation by intact grass-soil cores using $15 \mathrm{~N} 2$ and acetylene reduction. Soil Boil. Biochem. 1985, 17, 87-91. [CrossRef]

138. Tjepkema, J.; Burris, R. Nitrogenase activity associated with some wisconsin prairie grasses. Plant Soil 1976, 45, 81-94. [CrossRef]

139. Compant, S.; Nowak, J.; Coenye, T.; Clément, C.; Ait Barka, E. Diversity and occurrence of Burkholderia spp. in the natural environment. FEMS Microbiol. Rev. 2008, 32, 607-626. [CrossRef]

140. Oldroyd, G.E.; Murray, J.D.; Poole, P.S.; Downie, J.A. The Rules of Engagement in the Legume-Rhizobial Symbiosis. Annu. Rev. Genet. 2011, 45, 119-144. [CrossRef] [PubMed]

141. Oldroyd, G.E. Speak, friend, and enter: Signalling systems that promote beneficial symbiotic associations in plants. Nat. Rev. Microbiol. 2013, 11, 252. [CrossRef] [PubMed]

142. Bailey-Serres, J.; Parker, J.E.; Ainsworth, E.A.; Oldroyd, G.E.D.; Schroeder, J.I. Genetic strategies for improving crop yields. Nature 2019, 575, 109-118. [CrossRef] [PubMed]

143. Deng, Y.; Wu, T.; Wang, M.; Shi, S.; Yuan, G.; Li, X.; Chong, H.; Wu, B.; Zheng, P. Enzymatic biosynthesis and immobilization of polyprotein verified at the single-molecule level. Nat. Commun. 2019, 10, 2775. [CrossRef] 
144. Rubio, L.M.; Ludden, P.W. Biosynthesis of the iron-molybdenum cofactor of nitrogenase. Annu. Rev. Microbiol. 2008, 62. [CrossRef]

145. Curatti, L.; Rubio, L.M. Challenges to develop nitrogen-fixing cereals by direct nif-gene transfer. Plant Sci. 2014, 225, 130-137. [CrossRef]

146. Griesmann, M.; Chang, Y.; Liu, X.; Song, Y.; Haberer, G.; Crook, M.B.; Billault-Penneteau, B.; Lauressergues, M.; Keller, J.; Imanishi, L.; et al. Phylogenomics reveals multiple losses of nitrogen-fixing root nodule symbiosis. Science 2018, 361, eaat1743. [CrossRef]

147. Van Velzen, R.; Holmer, R.; Bu, F.; Rutten, L.; Van Zeijl, A.; Liu, W.; Santuari, L.; Cao, Q.; Sharma, T.; Shen, D.; et al. Comparative genomics of the nonlegume Parasponia reveals insights into evolution of nitrogen-fixing rhizobium symbioses. Proc. Natl. Acad. Sci. USA 2018, 115, E4700-E4709. [CrossRef]

148. Savka, M.A.; Farrand, S.K. Modification of rhizobacterial populations by engineering bacterium utilization of a novel plant-produced resource. Nat. Biotechnol. 1997, 15, 363. [CrossRef]

149. Knee, E.M.; Gong, F.-C.; Gao, M.; Teplitski, M.; Jones, A.R.; Foxworthy, A.; Mort, A.J.; Bauer, W.D. Root Mucilage from Pea and Its Utilization by Rhizosphere Bacteria as a Sole Carbon Source. Mol. Plant-Microbe Interact. 2001, 14, 775-784. [CrossRef]

150. Rossbach, S.; McSpadden, B.; Kulpa, D.; Rasul, G.; Ganoof, M.; De Bruijn, F.J. Use of rhizopine synthesis and catabolism genes to monitor soil bacteria and to create biased rhizospheres. Mol. Ecol. 1994, 3, 610-611.

151. Hawkesford, M.J. Reducing the reliance on nitrogen fertilizer for wheat production. J. Cereal Sci. 2014, 59, 276-283. [CrossRef] [PubMed]

152. Ivleva, N.B.; Groat, J.; Staub, J.M.; Stephens, M. Expression of active subunit of nitrogenase via integration into plant organelle genome. PLoS ONE 2016, 11, e0160951. [CrossRef] [PubMed]

153. López-Torrejón, G.; Jimenez-Vicente, E.; Buesa, J.M.; Hernandez, J.A.; Verma, H.K.; Rubio, L.M. Expression of a functional oxygen-labile nitrogenase component in the mitochondrial matrix of aerobically grown yeast. Nat. Commun. 2016, 7, 11426. [CrossRef]

154. Hiruma, K.; Gerlach, N.; Sacristán, S.; Nakano, R.T.; Hacquard, S.; Kracher, B.; Neumann, U.; Ramirez, D.; Bucher, M.; O'Connell, R.J.; et al. Root Endophyte Colletotrichum tofieldiae Confers Plant Fitness Benefits that Are Phosphate Status Dependent. Cell 2016, 165, 464-474. [CrossRef]

155. Murphy, P.; Wexler, W.; Grzemski, W.; Rao, J.; Gordon, D. Rhizopines-Their role in symbiosis and competition. Soil Boil. Biochem. 1995, 27, 525-529. [CrossRef]

156. Savka, M.A.; Dessaux, Y.; Gardener, B.B.M.; Mondy, S.; Kohler, P.R.A.; Rossbach, S. The "Biased Rhizosphere" Concept and Advances in the Omics Era to Study Bacterial Competitiveness and Persistence in the Phytosphere. Mol. Microb. Ecol. Rhizosphere 2013, 1, 1145-1161.

157. Wexler, M.; Gordon, D.; Murphy, P. The distribution of inositol rhizopine genes in Rhizobium populations. Soil Boil. Biochem. 1995, 27, 531-537. [CrossRef]

158. Gordon, D.M.; Ryder, M.H.; Heinrich, K.; Murphy, P.J. An Experimental Test of the Rhizopine Concept in Rhizobium meliloti. Appl. Environ. Microbiol. 1996, 62, 3991-3996. [CrossRef]

159. Murphy, P.J.; Trenz, S.P.; Grzemski, W.; De Bruijn, F.J.; Schell, J. The Rhizobium meliloti rhizopine mos locus is a mosaic structure facilitating its symbiotic regulation. J. Bacteriol. 1993, 175, 5193-5204. [CrossRef]

160. Murphy, P.J.; Heycke, N.; Banfalvi, Z.; Tate, M.E.; De Bruijn, F.; Kondorosi, A.; Tempé, J.; Schell, J. Genes for the catabolism and synthesis of an opine-like compound in Rhizobium meliloti are closely linked and on the Sym plasmid. Proc. Natl. Acad. Sci. USA 1987, 84, 493-497. [CrossRef] [PubMed]

161. Geddes, B.A.; Paramasivan, P.; Joffrin, A.; Thompson, A.L.; Christensen, K.; Jorrin, B.; Brett, P.; Conway, S.J.; Oldroyd, G.E.D.; Poole, P.S. Engineering transkingdom signalling in plants to control gene expression in rhizosphere bacteria. Nat. Commun. 2019, 10, 1-11. [CrossRef] [PubMed]

(C) 2020 by the authors. Licensee MDPI, Basel, Switzerland. This article is an open access article distributed under the terms and conditions of the Creative Commons Attribution (CC BY) license (http://creativecommons.org/licenses/by/4.0/). 